\title{
Mitochondrial evidence for distinct phylogeographic units in the endangered Malagasy poison frog Mantella bernhardi
}

\author{
DAVID R. VIEITES, ${ }^{*}$ YLENIA CHIARI, $+\ddagger$ MIGUEL VENCES, ${ }^{* * *}$ FRANCO ANDREONE,§FALITIANA \\ RABEMANANJARA, I†PARFAIT BORA,IISANDRA NIETO-ROMÁN** and AXEL MEYER† \\ *Museum of Vertebrate Zoology and Department of Integrative Biology, 3101 Valley Life Sciences Bldg., University of California, \\ Berkeley, CA 94720-3160, USA, +Lehrstuhl für Zoologie und Evolutionsbiologie, Department of Biology, University of Konstanz, \\ 78457 Konstanz, Germany, $\ddagger$ Institute for Biodiversity and Ecosystem Dynamics, Zoological Museum, University of Amsterdam, \\ PO Box 94766, 1090 GT Amsterdam, The Netherlands, §Museo Regionale di Scienze Naturali, Via G. Giolitti, 36, 10123 Torino, Italy, \\ IIDépartement de Biologie Animale, Université d'Antananarivo, Antananarivo 101, Madagascar, **Laboratorio de Anatomía Animal, \\ Departamento de Bioloxía Animal, Universidade de Vigo 36200, Vigo, Galicia, Spain, ***Present address: Zoological Institute, \\ Technical University of Braunschweig, Spielmannstr. 8, 38106 Braunschweig, Germany
}

\begin{abstract}
Mantella bernhardi is an endemic species of Malagasy poison frog threatened by loss and fragmentation of its natural habitat and collection for the pet trade. It is classified as threatened according to the International Union for Conservation of Nature and Natural Resources (IUCN) categories and included in Appendix II of the Convention on the International Trade of Endangered Species (CITES). A recent survey has increased the known distributional range of the species from one to eight populations across southeastern Madagascar, but little is known about its biology and genetic diversity. Here we estimate inter- and intrapopulation mitochondrial genetic variation of four populations. Populations from the northern and southern parts of the distributional range showed a high degree of divergence (maximum of $\mathbf{1 1 . 3 5 \%}$ in cytochrome $b$ ) and were recovered as reciprocally monophyletic groups. Nine haplotypes were detected in the northern and 12 in the southern populations. The population from Ranomafana National Park showed the lowest number of haplotypes and nucleotide diversity, and shared its most common haplotype with the second northern population from Tolongoina. All the other detected haplotypes were unique to each of the four populations. This suggests the existence of important barriers to gene flow, pre-dating human colonization of Madagascar at about 2000 years ago, in distinct contrast to other Mantella species that show a high degree of haplotype sharing throughout their range. The continued habitat fragmentation within the distribution range of $M$. bernhardi prevents any connection between its populations. Our data indicate the existence of at least two different management units for conservation in this species, corresponding to the North and South of its distribution range, and highlight the existence of strong regional endemism in southeastern Madagascar.
\end{abstract}

Keywords: amphibians, conservation, cytochrome b, Madagascar, Mantella bernhardi, phylogeography

Received 28 September 2005; revision accepted 8 December 2005

\section{Introduction}

The evolution of species diversity in rainforests has captured much attention of researchers due to the high biodiversity of tropical regions. There have been a number

Correspondence: David R. Vieites, Fax: (510) 6438238; E-mail: vieites@berkeley.edu of hypotheses that explain diversification in rainforest faunas, based on neutral or adaptive processes (reviewed by Moritz et al. 2000). Among these, the riverine model, with major rivers acting as an isolating barrier driving allopatric differentiation, seems to be especially relevant for taxa of low dispersal capacity, and has initially been applied to explain differentiation patterns of primates (Wallace 1852; Ayres \& Clutton-Brock 1992). In Sulawesi, 
areas of endemism were defined using phylogeographic patterns of monkeys. These areas show a remarkable congruence with those defined using similar methods for toads. This indicates that similar processes may drive differentiation in these taxa (Evans et al. 2003).

Amphibians are a group belonging to the lower end of the relative dispersal ability spectrum (e.g. Inger \& Voris 2001; Brown \& Guttman 2002), although transoceanic colonizations have been demonstrated for a number of taxa (Hedges et al. 1992; Kaiser et al. 1994; Vences et al. 2003). Molecular studies in amphibians have usually revealed strong phylogeographic structure and limited gene flow among populations (e.g. García-París et al. 2000; Wake \& Jockusch 2000; Kraaijeveld-Smit et al. 2005), although several species from the Palearctic and Nearctic have colonized wide ranges after the last glaciation and show very limited mitochondrial variability in these areas (e.g. Alexandrino et al. 2000; Steinfartz et al. 2000; Babik et al. 2004; Kuchta \& Tan 2005). Many other amphibian species, however, show high levels of intraspecific mitochondrial divergence (e.g. James \& Moritz 2000; Vences et al. 2005).

Madagascar is an ideal model region to test for general patterns of phylogeographic differentiation in amphibians. This island harbours a highly diverse and endemic amphibian fauna, which largely evolved in isolation due to the limited dispersal to and from other landmasses (Glaw \& Vences 2003). Moreover, the Madagascan geography is of a relatively simple pattern, with a western arid region separated from the eastern rainforests by a central mountain chain. The eastern rainforest is interrupted only by rivers that flow down from the central highlands in a westeast direction into the Indian Ocean. The western dry and spiny forests are separated by rivers flowing in the opposite direction into the Mozambique Channel. These rivers are known to form significant phylogeographic barriers for lemurs (Pastorini et al. 2003). A mid-domain effect largely influences amphibian diversity, being highest at midaltitudes and in the central-eastern rainforests (Lees 1996; Lees et al. 1999). So far, phylogeographic studies in Madagascan amphibians have mainly focused on Malagasy poison frogs, genus Mantella, and have found a relatively low degree of phylogeographic structure and common haplotype sharing in species from mid-altitude rainforest (Chiari et al. 2004, in press; Vences et al. 2004).

Mantella bernhardi is a species of Malagasy poison frog endemic to southeastern Madagascar and classified as endangered in the International Union for Conservation of Nature and Natural Resources (IUCN) Red List (Andreone et al. 2005). It was until recently known from only a single locality that suffers from habitat destruction and represented the only source population for the pet trade (Raxworthy \& Nussbaum 2000). Recent fieldwork has considerably extended the known range of this species by the discovery of seven new populations, all in low-altitude rainforests (Rabemananjara et al. 2005). Here we provide data on the mitochondrial genetic structure within and among four populations of $M$. bernhardi from the northern and southern parts of its distribution area. The data indicate a surprisingly strong phylogeographic structuring in this low-altitude species, which we discuss in terms of a possible differentiation due to riverine barriers. Our findings also have implication for conservation actions, indicating the need of at least two separate managing units within M. bernhardi for conservation purposes.

\section{Materials and methods}

\section{Sample collection}

Tissue samples were collected in January and February 2004 in four of the eight known populations, spanning over most of the distributional range of Mantella bernhardi (Rabemananjara et al. 2005): Ranomafana National Park $\left(21.4^{\circ} \mathrm{S}, 47.5^{\circ} \mathrm{E}\right)$, Tolongoina $\left(21.55^{\circ} \mathrm{S}, 47.52^{\circ} \mathrm{E}\right)$, Manombo Special Reserve $\left(23.0^{\circ} \mathrm{S}, 47.7^{\circ} \mathrm{E}\right)$, and Vevembé $\left(22.8^{\circ} \mathrm{S}\right.$, $\left.47.0^{\circ} \mathrm{E}\right)$. We collected one toe-clip from each individual, which was preserved in absolute ethanol, releasing immediately the animals after treating wounds with antiseptic. Sample sizes are given for each locality in Table 1.

\section{DNA extraction and sequencing}

Total genomic DNA was extracted using proteinase $\mathrm{K}$ (final concentration $1 \mathrm{mg} / \mathrm{mL}$ ), and isolated by a standard salt extraction protocol (Bruford et al. 1992). A fragment of the mitochondrial cytochrome $b$ gene was amplified via polymerase chain reaction (PCR) using the primers Cytb-c and CBJ10933 (Bossuyt \& Milinkovitch 2000). PCRs were performed in $25-\mu \mathrm{L}$ reactions using $50 \mathrm{ng}$ genomic DNA, $10 \mathrm{pmol}$ of each primer, $15 \mathrm{nmol}$ of each $\mathrm{dNTP}, 50 \mathrm{nmol}$ additional $\mathrm{MgCl}_{2}$ and the REDTaq PCR buffer (10 mM Tris- $\mathrm{HCl}, \mathrm{pH} 8.3,50 \mathrm{~mm} \mathrm{KCl}, 1.1 \mathrm{~mm} \mathrm{MgCl}_{2}$ and $0.01 \%$ gelatine) and $1 \mathrm{U}$ of REDTaq DNA polymerase (Sigma). PCR conditions were as follows: an initial denaturation step at $94{ }^{\circ} \mathrm{C}$ for $90 \mathrm{~s} ; 35$ cycles at $94^{\circ} \mathrm{C}$ for $30 \mathrm{~s}$, annealing temperature of $53^{\circ} \mathrm{C}$ for $45 \mathrm{~s}$, extension at $72{ }^{\circ} \mathrm{C}$ for $60 \mathrm{~s}$; final extension of $10 \mathrm{~min}$ at $72{ }^{\circ} \mathrm{C}$. PCR products were purified using QIAquick spin columns (QIAGEN) prior to cycle sequencing. A $10-\mu \mathrm{L}$ sequencing reaction included $1-2 \mu \mathrm{L}$ of template, $1 \mu \mathrm{L}$ of sequencing buffer, $2 \mu \mathrm{L}$ of 2 pmol primer, $1.8 \mu \mathrm{L}$ of $\mathrm{ABI}$ sequence mix (BigDye Terminator version 3.1 Sequencing Standard, Applied Biosystems) and 3.2-4.2 $\mu \mathrm{L}$ of water. The sequence reaction was 33 cycles of $10 \mathrm{~s}$ at $96^{\circ} \mathrm{C}, 10 \mathrm{~s}$ at $50{ }^{\circ} \mathrm{C}$ and $4 \mathrm{~min}$ at $60^{\circ} \mathrm{C}$. Sequence data collection and visualization were performed on an ABI 3100 automated sequencer (Applied Biosystems). Sequences were deposited in GenBank; accession numbers DQ278651-DQ278803. 
Table 1 Summary of mitochondrial DNA diversity for samples of Mantella bernhardi used in this study and other species of Mantella for comparison

\begin{tabular}{|c|c|c|c|c|c|}
\hline Species and population & Sample size & Haplotypes & Polymorphic sites & $\begin{array}{l}\text { Haplotype diversity } \\
\text { (Hd) }\end{array}$ & $\begin{array}{l}\text { Nucleotide diversity } \\
(\mathrm{Pi}) \times 100\end{array}$ \\
\hline \multicolumn{6}{|l|}{ M. bernhardi } \\
\hline Ranomafana - N (1) & 25 & 2 & 2 & $0.08 \pm 0.07$ & $0.03 \pm 0.03$ \\
\hline Tolongoina - N (1) & 37 & 8 & 9 & $0.47 \pm 0.10$ & $0.15 \pm 0.04$ \\
\hline Manombo - S (1) & 66 & 7 & 21 & $0.33 \pm 0.07$ & $0.27 \pm 0.09$ \\
\hline Vevembe - S (1) & 25 & 5 & 4 & $0.38 \pm 0.12$ & $0.10 \pm 0.04$ \\
\hline \multicolumn{6}{|l|}{ M. milotympanum } \\
\hline Fierenana (2) & 20 & 9 & 14 & $0.79 \pm 0.09$ & $0.65 \pm 0.39$ \\
\hline \multicolumn{6}{|l|}{ M. crocea } \\
\hline Ihofa (2) & 26 & 10 & 11 & $0.85 \pm 0.05$ & $0.50 \pm 0.31$ \\
\hline Ambohimanarivo (2) & 7 & 2 & 4 & $0.57 \pm 0.12$ & $0.43 \pm 0.31$ \\
\hline Savakoanina (2) & 15 & 8 & 7 & $0.87 \pm 0.07$ & $0.38 \pm 0.25$ \\
\hline Andriabe (2) & 13 & 7 & 9 & $0.73 \pm 0.13$ & $0.35 \pm 0.24$ \\
\hline North of Fierenana (2) & 2 & 2 & 2 & $1.00 \pm 0.50$ & $0.38 \pm 0.46$ \\
\hline \multicolumn{6}{|l|}{ M. aurantiaca } \\
\hline Torotorofotsy 1 (2) & 6 & 2 & 7 & $0.62 \pm 0.11$ & $0.33 \pm 0.22$ \\
\hline Torotorofotsy 2 (2) & 5 & 2 & 2 & $0.40 \pm 0.24$ & $0.15 \pm 0.15$ \\
\hline Andranomena (2) & 10 & 4 & 48 & $0.68 \pm 0.12$ & $2.47 \pm 1.32$ \\
\hline Andranomandry (2) & 16 & 11 & 36 & $0.93 \pm 0.05$ & $2.00 \pm 1.08$ \\
\hline \multicolumn{6}{|l|}{ M. madagascariensis } \\
\hline Marolambo (3) & 7 & 4 & 6 & $0.81 \pm 0.13$ & $0.32 \pm 0.22$ \\
\hline \multicolumn{6}{|l|}{ M. baroni } \\
\hline Farimazava (4) & 33 & 26 & 42 & $0.97 \pm 0.02$ & $1.24 \pm 0.29$ \\
\hline Mantady (4) & 1 & 1 & - & - & - \\
\hline Vohidrazana (4) & 10 & 8 & 12 & $0.93 \pm 0.08$ & $0.49 \pm 0.10$ \\
\hline Andranomena (4) & 2 & 2 & 3 & $1.00 \pm 0.50$ & $0.57 \pm 0.29$ \\
\hline Ranomafana (4) & 13 & 12 & 20 & $0.99 \pm 0.04$ & $0.70 \pm 0.10$ \\
\hline Tsinjoarivo (4) & 3 & 2 & 1 & $0.67 \pm 0.31$ & $0.13 \pm 0.06$ \\
\hline Andriave (4) & 5 & 3 & 2 & $0.80 \pm 0.16$ & $0.19 \pm 0.05$ \\
\hline \multicolumn{6}{|l|}{ M. cowani } \\
\hline Soamazaka (4) & 4 & 3 & 4 & $0.83 \pm 0.22$ & $0.38 \pm 0.15$ \\
\hline Vohisokina (4) & 20 & 8 & 15 & $0.77 \pm 0.08$ & $0.54 \pm 0.10$ \\
\hline Vatolampy (4) & 6 & 3 & 2 & $0.73 \pm 0.16$ & $0.22 \pm 0.16$ \\
\hline Farimazava (4) & 8 & 5 & 25 & $0.79 \pm 0,15$ & $1.88 \pm 0.71$ \\
\hline
\end{tabular}

References are given in parentheses: 1, this study; 2, Chiari et al. (2004); 3, Vences et al. (2004); 4, Chiari et al. (in press). For M. bernhardi, $\mathrm{N}$ and $\mathrm{S}$ identify northern and southern populations, respectively. Values are given \pm standard deviation.

\section{Data analysis}

Sequences (502 bp) were edited and aligned using SEQUENCE NAVIGATOR software (Applied Biosystems). We did not detect stop codons or indels in the alignment. Haplotypes were merged using the program COLLAPSE version 1.2 (Posada 1999). Phylogenetic analyses were performed using the programs PAUP ${ }^{*}$, version $4 \mathrm{~b} 10$ (Swofford 2002), and MRBAYES, version 3.1 (Ronquist \& Huelsenbeck 2003). We performed both a Bayesian and maximum-parsimony (MP) analysis in order to check for consistency in the results using different algorithms based on different assumptions of molecular evolution. MP analysis was performed in PAUP* $4 \mathrm{~b} 10$ using heuristic searches with tree-bisection-reconnection (TBR) branch swapping, step addition starting tree, and random addition sequence with 1000 replicates, using distinct haplotypes. We used two species of mantellids as outgroups: Mantella baroni and Boophis ankaratra. For the Bayesian analysis, we partitioned our data by codon position, as this partitioning strategy performs better with protein-coding mtDNA (Brandley et al. 2005). MRMODELTEST version 2.2 [Nylander 2004; modified version of MODELTEST 3.6 (Posada \& Crandall 1998)] was employed to choose the appropriate 
model of sequence evolution for each partition. We standardized the initial tree used for calculation of every partition model, by using a neighbour-joining (NJ) tree with Jukes-Cantor substitution model of the whole data set as starting tree, instead of a random NJ tree as is defined in MRMODELTEST by default. The models selected were $\mathrm{K} 80+\mathrm{G}$, HKY and GTR for the partitions of the first, second and third codon positions, respectively. The analysis consisted of four Markov chains that ran for $10 \times 10^{6}$ generations, sampled every 1000 generations, with a random starting tree, default priors and equal branch lengths for each partition. The burn-in parameter was empirically estimated by plotting -ln L against the generation number, and the trees corresponding to the first million generations discarded.

For each population we assessed nucleotide diversity and haplotype diversity using the program DNASP version 4.0 (Rozas et al. 2003). The method of statistical parsimony (Templeton et al. 1992) implemented in the TCS software package (Clement et al. 2000) was employed to depict phylogenetic and geographical relationships among the identified haplotypes. The program first defines the uncorrected distance between haplotypes above which the parsimony criterion is violated with more than $5 \%$ of probability, and then establishes connections between the haplotypes until the 'parsimony' limit is reached. Ambiguities were solved following the frequency, topological and geographical criteria (Crandall \& Templeton 1993; Templeton \& Sing 1993; Crandall et al. 1994; Posada \& Crandall 2001).

\section{Results}

We obtained sequences for 153 individuals of Mantella bernhardi, ranging from 25 to 66 individuals per population (Table 1). Of the 502 bp of the cytochrome $b$ gene analysed, 420 were constant and 64 were parsimony-informative. The $M$. bernhardi sequences contained 77 variable sites, which defined 23 haplotypes; haplotype and nucleotide diversity values are summarized in Table 1. Haplotype diversity was highest in Tolongoina, and lowest in Ranomafana. Nucleotide diversity was highest at Manombo, second highest at Tolongoina, and lowest at Ranomafana.

The trees resulting from Bayesian (Fig. 1) and MP analyses consistently recovered two reciprocally monophyletic haploclades. MP searches recovered a single most parsimonious tree (consistency index 0.90, retention index 0.97; not shown). The two clades, corresponding to the two northern and the two southern populations, respectively, were supported with high $(100 \%)$ bootstrap values. The northern populations constituted a single haploclade, while in the southern clade the Vevembé population was supported by high bootstrap values as a different entity. The Bayesian tree agreed in the general topology with the MP tree, with high support for the two above-mentioned clades.

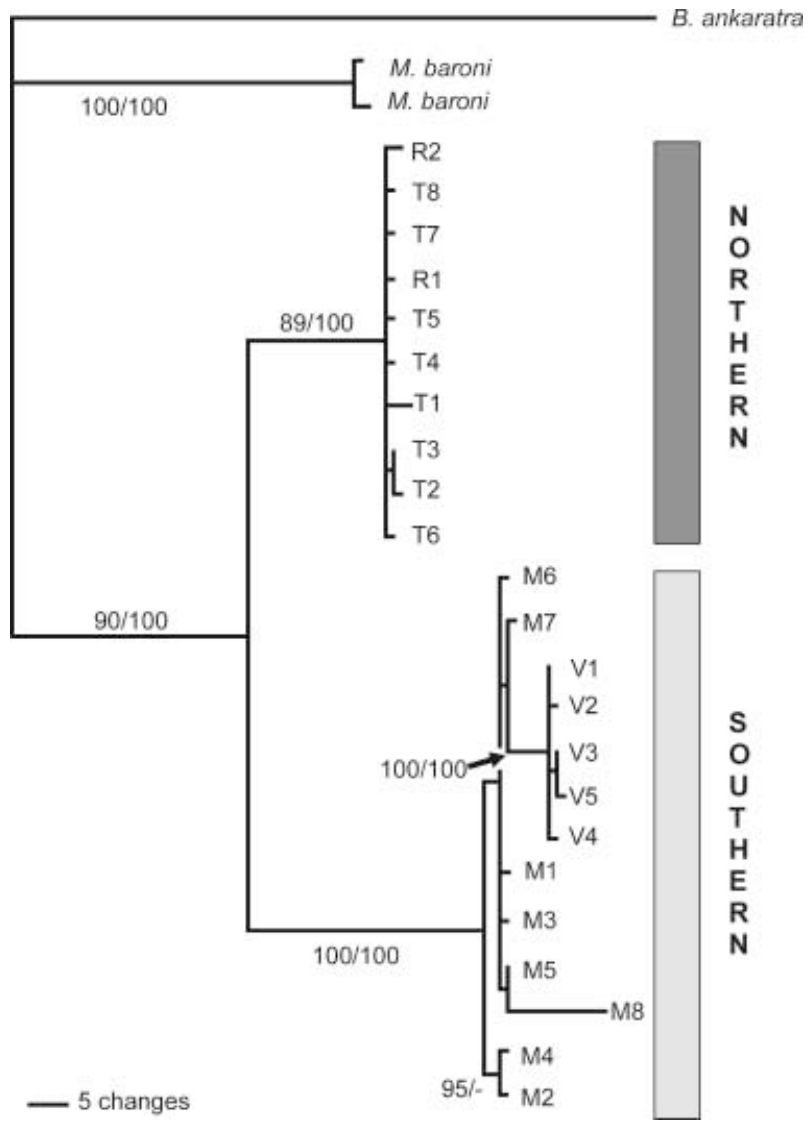

Fig. 1 Bayesian phylogram of the observed haplotypes showing the two clades of Mantella bernhardi. Haplotype codes refer to the first letter of each population and the number of that haplotype (R, Ranomafana; T, Tolongoina; V, Vevembé; M, Manombo). Bayesian posterior probabilities and bootstrap values higher than $85 \%$ in the Bayesian and MP analyses, respectively, are shown (BY/MP).

These results were congruent also with TCs analysis, which recovered two haplotype networks corresponding to the northern and southern populations, respectively (Fig. 2). Manombo (with eight haplotypes) and Vevembé (five haplotypes) had no haplotypes in common, nor did either share any haplotype with northern populations. In the two northern populations (Ranomafana and Tolongoina), one haplotype predominated (R1, Fig. 2), and was shared between both. The Ranomafana population showed very low genetic diversity, with only two haplotypes detected vs. eight unique haplotypes in Tolongoina. Most of the sampled specimens in the northern populations (96\%) shared the same haplotype. We had to force the program to a minimum of 48 steps to connect the two networks between the haplotype R2 and M1 (Fig. 2). In the southern haplotype network, Vevembé haplotypes constituted again a separate entity within the southern clade. 


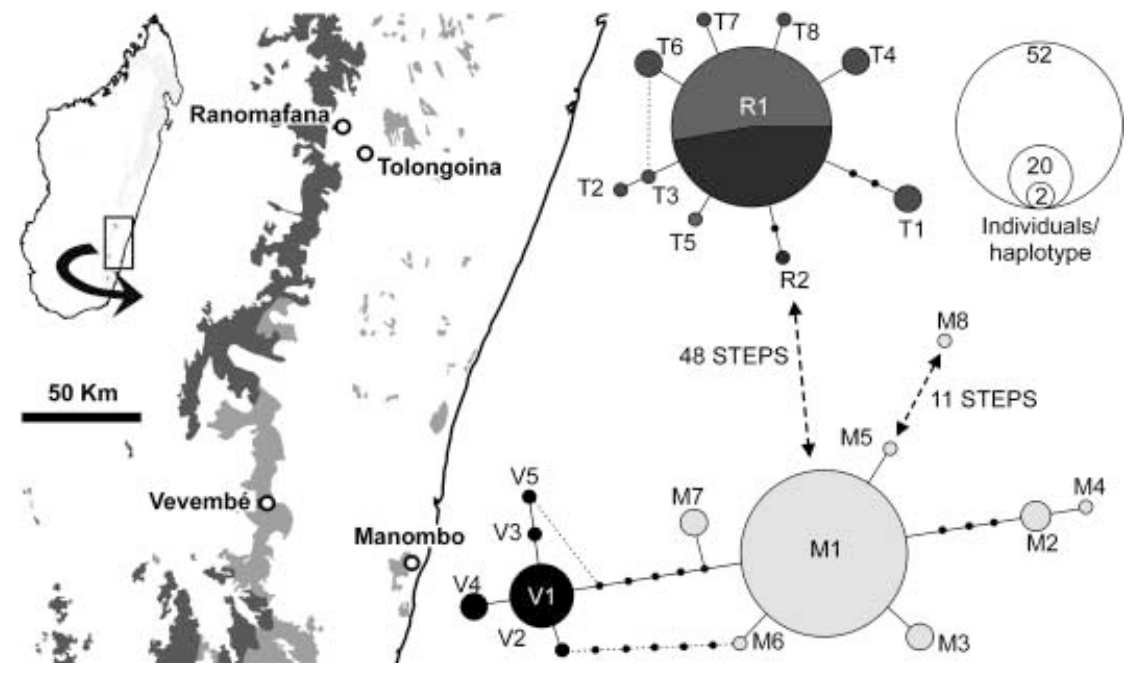

Fig. 2 Haplotype network of the four studied populations under the $95 \%$ cladogram estimation in TCs. Haplotype codes are the same as in Fig. 1, and alternative nodes are indicated by dashed lines. Only Ranomafana and Tolongoina shared a haplotype; all other haplotypes were unique to single populations. The program had to be forced to connect the two haploclades (see text). Geographic relationships of the sampled populations is shown on the left; light grey and dark grey represent, respectively, low-altitude and mid-altitude natural rainforest.

\section{Discussion}

\section{Riverine barriers and phylogeography}

Our data suggest the presence of two reciprocally monophyletic mitochondrial lineages within Mantella bernhardi, corresponding to the northern and southern populations, respectively. The high mtDNA divergence between these haploclades (with a maximum of 57 substitutions and $11.35 \%$ divergence between haplotypes $\mathrm{T} 1$ and $\mathrm{V} 4$ ), indicates long-term differentiation. This pattern stands in remarkable contrast to other species of Mantella from midaltitude rainforest areas in Madagascar (Table 1). In one of these species, Mantella baroni, based on the analysis of a cytochrome $b$ fragment homologous to the one used here, populations from the northernmost and southernmost regions largely shared similar or even identical haplotypes (Chiari et al. in press). Of the 17 species of Mantella recognized by Vences et al. (1999), six have so far been studied from a phylogeographic perspective: M. baroni, Mantella cowani (Chiari et al. in press), Mantella aurantiaca, Mantella crocea, and Mantella milotympanum (Chiari et al. 2004), and Mantella madagascariensis (Vences et al. 2004). Values of haplotype diversity (= gene diversity) and nucleotide diversity for these species are summarized in Table 1. Haplotype diversity ranged from 0.6 to 0.99 (counting populations where more than five individuals were sequenced), with most values higher than 0.6. Haplotypes within the M. crocea/milotympanum complex, and within $M$. aurantiaca, had maximum divergences of eight steps. Compared with these data, M. bernhardi, by contrast, is characterized by relatively lower haplotype diversity within populations (Table 1), but a higher among-population haplotype differentiation.

To reliably ascertain whether this interpopulational differentiation in M. bernhardi is due to fully disrupted gene flow or to a possible lower dispersal capacity of females, nuclear markers such as microsatellites are necessary. Such a male-biased dispersal pattern has been inferred by Lampert et al. (2003) in túngara frogs, and observed by Joly \& Grolet (1996) for juvenile Alpine newts, Triturus alpestris, although evidence for female-biased dispersal was found in bullfrogs, Rana catesbeiana, by Austin et al. (2000), and in common frogs, Rana temporaria, by Palo et al. (2004). A further hypothesis that needs to be taken into account is that phylogeographic discontinuities in nonrecombining units such as mitochondrial genes may arise in continuously distributed species in the absence of gene flow if individual dispersal distances and population sizes are low (Irwin 2002). For M. bernhardi, our own unpublished data indicate high local population densities of 170-820 individuals per hectare, but nothing is known about individual dispersal distances. However, the fact that very few populations of this species are known and that it had eluded scientific collection before the 1990s (Rabemananjara et al. 2005) indicate that a historically continuous distribution is very unlikely. A phylogeographic discontinuity is not only present between northern and southern populations of this species but also (although much less pronounced) between Manombo and Vevembé. The high interpopulational divergences and the complete absence of haplotype sharing between north and south, and between Manombo and Vevembé, are therefore best explained by a long genetical isolation of these populations. Although the habitat of $M$. bernhardi is currently heavily fragmented, the available information suggests that most of the forest disappeared recently (Green \& Sussman 1990) due to human activities. The amount of genetic divergence between the northern and southern haplotype groups are of a level that indicates the presence of barriers to gene flow pre-dating human colonization of Madagascar which is likely to have occurred less than 2000 years ago (Burney et al. 2003). 
Comparisons of phylogeographic patterns for multiple codistributed species is a powerful tool to detect potential long-term spatial barriers to gene flow (Bermingham \& Moritz 1998). Based on the Riverine Barrier Model (Wallace 1852; Ayres \& Clutton-Brock 1992), large rivers facilitate genetic diversification in terrestrial organisms reducing the gene flow. However, the influence of rivers in this respect is controversial. Gascon et al. (2000) found no influence of a river in the Amazon basin on the present-day pattern of community similarity and species richness of frogs and marsupials. Lougheed et al. (1999) found a limited influence of a riverine barrier on the phylogeographic pattern of a frog species, Epipedobates femoralis, and Lugon-Moulin et al. (1999) found no significance influence of riverine barriers on the gene flow of the common shrew, Sorex araneus, in France. On the other hand, rivers are known to provide barriers to gene flow in primates (Peres et al. 1996; Eriksson et al. 2004), reptiles (Pellegrino et al. 2005), and even in understorey forest birds (Capparella 1991).

In Madagascar, Pastorini et al. (2003) provided evidence for a significant influence of several large rivers in western Madagascar on lemur phylogeography, but their data were insufficient to analyse the situation in the east. However, several more detailed studies indicated the existence of a genetic barrier between Ranomafana and Manombo/ Vevembé. The black and white ruffed lemurs (Varecia variegata) are present both in Ranomafana and in Manombo, showing a high degree of genetic differentiation between the two sites (Louis et al. 2005). The same pattern of genetic differentiation has been found in brown lemurs (Eulemur fulvus/albocollaris), although in this case a stable hybrid zone was recorded in Andringitra National Park (between Vevembé and Ranomafana) (Sterling \& Ramarason 1996). In this species, a putative barrier was located in the Manampatrana River (= Iantara River), which divides northern and southern lemur populations, appearing to serve as an important boundary in this hybrid zone (Wyner et al. 2002). Unfortunately, these studies on lemurs do not use a homologous genetic marker, and a direct comparison of the depth of the genetic divergences encountered in lemurs and frogs is therefore not possible. However, although there is little phylogeographic information concerning Malagasy amphibians, and existing works concern species from other parts of Madagascar (i.e. Chiari et al. 2004, in press; Vences et al. 2004), our data reinforce recent evidence that they might be diverged in response to similar barriers to gene flow as primates (Evans et al. 2003).

As pointed out by Peres et al. (1996), the specific characters of the riverine barriers need to be taken into account when studying their effect on gene flow. These authors found gene flow among adjacent subspecies of saddleback tamarins across Rio Jurua in Amazonia, but restricted to the headwater section of the river. In eastern Madagascar, rivers originate in the central highlands and flow eastwards into the Indian Ocean. These rivers obviously become larger towards lower altitudes, and therefore may constitute important barriers to species restricted to low-altitude habitat. This scenario could still explain why there is distinct interpopulational differentiation in the low-altitude specialist $M$. bernhardi while the mid-altitude M. baroni shows no relevant population subdivision (Chiari et al. in press). More intensive sampling of low-altitude specialists among Madagascan frog species is necessary to assess the impact of rivers, especially the Manampatrana River, on their genetic differentiation.

\section{Management units for conservation in Mantella bernhardi}

Madagascar is one region that deserves highest priority for biodiversity conservation (Myers et al. 2000). Amphibians are a group that is globally affected by important declines (Stuart et al. 2004), and in Madagascar all amphibian species but one (recently introduced) are endemic (Glaw \& Vences 2003). For many of them fundamental data are lacking to reliably assess conservation priorities (Andreone \& Luiselli 2003; Andreone et al. 2005). Rainforest destruction has been identified as one of the major causes of the loss of the Malagasy biodiversity (Green \& Sussman 1990; Achard et al. 2002). Over-exploitation for the pet trade has also been identified as threat for a few species of Malagasy amphibians, especially of the genera Dyscophus and Mantella (Behra 1993; Andreone \& Luiselli 2003). Mantella are included on Appendix II of the Convention on the International Trade of Endangered Species (CITES), and the numbers exported from Madagascar amount to several thousand individuals per year.

One of the goals of modern conservation biology is not only to preserve species and habitats, but also their evolutionary potential in terms of maintaining the genetic diversity of the extant species. In this context, conservation or management units should be clearly defined. There are very different criteria for defining these units in practice (e.g. Ryder 1986; US Fish and Wildlife Service \& National Marine Fisheries Service 1996), and some can be controversial (e.g. Ryder 1986; Avise 1994; Moritz 1994; see review of Fraser \& Bernatchez 2001). We here follow the rather flexible concept of adaptive evolutionary conservation (AEC) as proposed by Fraser \& Bernatchez 2001). In this theoretical framework, an evolutionary significant unit (ESU) is a lineage demonstrating highly restricted gene flow from other such lineages within the higher organizational level of the species, and the best available biological information is used to exercise ESU definitions on a caseby-case basis. In M. bernhardi, the lack of habitat connection between southern and northern populations as assessed by Rabemananjara et al. (2005) (see also Fig. 2), and their 
strong genetic differentiation suggests considering them as ESUs under this concept. The comparatively low haplotype and nucleotide diversity found within populations of this species (Table 1) indicates that a rather limited genetic diversity may add to the vulnerability of single populations.

Amphibians seem to be less sensitive to reduction of habitat size than birds, small mammals or reptiles (Goodman \& Raherilalao 2003; Vallan 2003). The current isolation of $M$. bernhardi populations therefore probably does not represent an immediate threat, as long as some suitable habitat remains. Manombo and Ranomafana are protected as Special Reserve and National Park, respectively, but Vevembé is not. We suspect that the phylogeographic pattern observed in $M$. bernhardi is paralleled by other species. There are several other amphibian species that have been found by us at Vevembé but not at the other sites, and at least one of them (an undescribed species close to Boophis albilabris) may be a regional endemism. Hence, our data strongly suggest that this site merits inclusion in Madagascar's network of protected areas.

\section{Acknowledgements}

We are indebted to J. E. Cadle, E. Rajeriason, E. Randriamitso Andrianiaina, F. Glaw, D. R. Wake, C. Woodhead and Julie Barth for comments, informations or help during field and lab work. D. R. Vieites was supported by a grant of the University of Vigo for research in foreign countries and by NSF AmphibiaTree Grant EF0334939. Y. Chiari was supported by a grant of the Landesgraduiertenförderung Baden-Württemberg and an Ambassadorial scholarship of the Rotary Foundation. Laboratory and fieldwork received support from grants of the Deutsche Forschungsgemeinschaft to M. Vences and A. Meyer, and of the BIOPAT Foundation and the Volkswagen Foundation to M. Vences.

\section{References}

Achard F, Eva HD, Stibig H-J et al. (2002) Determination of deforestation rates of the world's humid tropical forests. Science, 297, 999-1002.

Alexandrino J, Froufe E, Arntzen JW, Ferrand N (2000) Genetic subdivision, glacial refugia and postglacial recolonization in the golden-striped salamander, Chioglossa lusitanica (Amphibia: Urodela). Molecular Ecology, 9, 771-781.

Andreone F, Luiselli LM (2003) Conservation priorities and potential threats influencing the hyper-diverse amphibians of Madagascar. Italian Journal of Zoology, 70, 53-63.

Andreone F, Cadle JE, Cox N et al. (2005) Global amphibian assessment for Madagascar: species diversity, red listing, and identification of conservation hotspots. Conservation Biology, 19, 1790-1802.

Austin JD, Dávila JA, Lougheed SC, Boag PT (2000) Genetic evidence for female-biased dispersal in the bullfrog, Rana catesbeiana (Ranidae). Molecular Ecology, 12, 3165-3172.

Avise JC (1994) Molecular Markers, Natural History and Evolution. Chapman \& Hall, New York.

Ayres JM, Clutton-Brock TH (1992) River boundaries and species range size in Amazonian primates. American Naturalist, 140, 531-537.

Babik W, Branicki W, Sandera M et al. (2004) Mitochondrial phylogeography of the moor frog, Rana arvalis. Molecular Eco$\log y, 13,1469-1480$.

Behra O (1993) The export of reptiles and amphibians from Madagascar. TRAFFIC Bulletin, 13, 115-116.

Bermingham E, Moritz C (1998) Comparative phylogeography: concept and applications. Molecular Ecology, 7, 367-369.

Bossuyt F, Milinkovitch MC (2000) Convergent adaptive radiations in Madagascan and Asian ranid frogs reveal covariation between larval and adult traits. Proceedings of the National Academy of Sciences, USA, 97, 6585-6590.

Brandley MC, Schmitz A, Reeder TW (2005) Partitioned Bayesian analyses, partition choice, and the phylogenetic relationships of scincid lizards. Systematic Biology, 54 (3), 373-390.

Brown RM, Guttman S (2002) Phylogenetic systematics of the Rana signata complex of Philippine and Bornean stream frogs: reconsideration of Huxley's modification of Wallace's Line at the Oriental-Australian faunal zone interface. Biological Journal of the Linnean Society, 76 (3), 393-461.

Bruford MW, Hanotte O, Brookfield JFY, Burke T (1992) Singlelocus and multilocus DNA fingerprint. In: Molecular Genetic Analysis of Populations: A Practical Approach (ed. Hoelzel AR), pp. 225-270. IRL Press, Oxford.

Burney DA, Robinson GS, Burney LP (2003) Sporormiella and the late Holocene extinctions in Madagascar. Proceedings of the National Academy of Sciences, USA, 19, 10800-10805.

Capparella A (1991) Neotropical avian diversity and riverine barriers. Acta XX Congressus Internationalis Ornithologici, 307316.

Chiari Y, Vences M, Vieites DR et al. (2004) New evidence for parallel evolution of colour patterns in Malagasy poison frogs (Mantella). Molecular Ecology, 13, 3763-3774.

Chiari Y, Andreone F, Vences M, Meyer A (in press) Genetic variation of an endangered Malagasy frog, Mantella cowani, and its phylogeographic relationship to the widespread M. baroni. Conservation Genetics.

Clement M, Posada D, Crandall KA (2000) тcs: a computer program to estimate gene genealogies. Molecular Ecology, 9, 1657-1659.

Crandall K, Templeton AR (1993) Empirical tests of some predictions from coalescent theory with applications to intraspecific phylogeny reconstruction. Genetics, 134, 959-969.

Crandall KA, Templeton AR, Sing CF (1994) Intraspecific cladogram estimation: problems and solutions. In: Models in Phylogeny Reconstruction (eds Scotland RW, Siebert DJ, Williams DM), pp. 273-297. Clarendon Press, Oxford.

Eriksson J, Hohmann G, Boesch C, Vigilant L (2004) Rivers influence the population genetic structure of bonobos (Pan paniscus) Molecular Ecology, 13, 3425-3435.

Evans BJ, Supriatna J, Andayani N et al. (2003) Monkeys and toads define areas of endemism on Sulawesi. Evolution, 57, 14361443.

Fraser DJ, Bernatchez L (2001) Adaptive evolutionary conservation: towards a unified concept for defining conservation units. Molecular Ecology, 10, 2741-2752.

García-París M, Good DA, Parra-Olea G, Wake DB (2000) Biodiversity of Costa Rican salamanders: implications of high levels of genetic differentiation and phylogeographic structure for species formation. Proceedings of the National Academy of Sciences, USA, 97, 1640-1647. 
Gascon C, Malcolm JR, Patton JL et al. (2000) Riverine barriers and the geographic distribution of Amazonian species. Proceedings of the National Academy of Sciences, USA, 97, 13672-13677.

Glaw F, Vences M (2003) Introduction to amphibians. In: The Natural History of Madagascar (eds Goodman SM, Benstead JP), pp. 883-898. University of Chicago Press, Chicago and London.

Goodman SM, Raherilalao MJ (2003) Effects of forest fragmentation on bird communities. In: The Natural History of Madagascar (eds Goodman SM, Benstead JP), pp. 1064-1066. University of Chicago Press, Chicago and London.

Green GM, Sussman R (1990) Deforestation history of the eastern rainforests of Madagascar from satellite images. Science, 248, 212-215.

Hedges SB, Hass CA, Maxson LR (1992) Caribbean biogeography: molecular evidence for dispersal in West Indian terrestrial vertebrates. Proceedings of the National Academy of Sciences, USA, 89, 1909-1913.

Inger RF, Voris HK (2001) The biogeographical relations of the frogs and snakes of Sundaland. Journal of Biogeography, 28, 863891.

Irwin DE (2002) Phylogeographic breaks without geographic barriers to gene flow. Evolution, 56, 2383-2394.

James CH, Moritz C (2000) Intraspecific phylogeography in the sedge frog Litoria fallax (Hylidae) indicates pre-Pleistocence vicariance of an open forest species from eastern Australia. Molecular Ecology, 9, 349-358.

Joly P, Grolet O (1996) Colonization dynamics of new ponds, and the age structure of colonizing Alpine newts, Triturus alpestris. Acta Oecologica, 17, 599-608.

Kaiser H, Sharbel TF, Green DM (1994) Systematics and biogeography of eastern Caribbean Eleutherodactylus (Anura: Leptodactylidae): evidence from allozymes. Amphibia-Reptilia, 15, 375-394.

Kraaijeveld-Smit FJL, Beebee TJC, Griffiths RA, Moore RD, Schley L (2005) Low gene flow but high genetic diversity in the threatened Mallorcan midwife toad Alytes muletensis. Molecular Ecology, 14, 3307-3315.

Kuchta SR, Tan AM (2005) Isolation by distance and post-glacial range expansion in the rough-skinned newt, Taricha granulosa. Molecular Ecology, 14, 225-244.

Lampert KP, Rand AS, Mueller UG, Ryan MJ (2003) Fine scale genetic pattern and evidence for sex-biased dispersal in the tungara frog, Physalaemus pustulosus. Molecular Ecology, 12, 3325-3334.

Lees DC (1996) The Perinet effect? Diversity gradients in an adaptive radiation of Madagascan butterflies (Satyrinae: Mycalesina) contrasted with other species-rich rainforest taxa. In: Actes $d u$ Colloque International Biogéographie de Madagascar (ed. Lourenço WR), pp. 479-490. Mémoires de la Société de Biogeographie, Paris.

Lees DC, Kremen C, Andramampiana L (1999) A null model for species richness gradients: bounded range overlap of butterflies and other rainforest endemics in Madagascar. Biological Journal of the Linnean Society, 67, 529-584.

Lougheed SC, Gascon C, Jones DA, Bogart JP, Boag PT (1999) Ridges and rivers: a test of competing hypotheses of Amazonian diversification using a dart-poison frog (Epipedobates femoralis) Proceedings of the Royal Society of London. Series B, Biological Sciences, 266, 1829-1835.

Louis EE Jr, Ratsimbazafy JH, Razakamaharauo VR et al. (2005) Conservation genetics of black and white ruffed lemurs, Varecia variegata, from southeastern Madagascar. Animal Conservation, 8, 105-111.

Lugon-Moulin N, Brunner H, Balloux F, Hausser J, Goudet J (1999) Do riverine barriers, history or introgression shape the genetic structuring of a common shrew (Sorex araneus) population? Heredity, 83, 155-161.

Moritz C (1994) Defining 'evolutionary significant units' for conservation. Trends in Ecology \& Evolution, 9, 373-375.

Moritz C, Patton JL, Schneider CJ, Smith TB (2000) Diversification of rainforest faunas. Annual Review of Ecology and Systematics, 31, 533-563.

Myers N, Mittermeier RA, Mittermeier CG, de Fonseca GAB, Kent J (2000) Biodiversity hotspots for conservation priorities. Nature, 403, 853-858.

Nylander JAA (2004) Mrmodeltest (version 2). Program distributed by the author. Evolutionary Biology Centre, Uppsala University.

Palo JU, Lesbarrres D, Schmeller DS, Primmer CR, Merilä J (2004) Microsatellite marker data suggest sex-biased dispersal in the common frog Rana temporaria. Molecular Ecology, 13, 28652869.

Pastorini J, Thalmann U, Martin RD (2003) A molecular approach to comparative phylogeography of extant Malagasy lemurs. Proceedings of the National Academy of Sciences, USA, 100, 5879_ 5884.

Pellegrino KCM, Rodrígues MT, Waite AN, Morando M, Yassuda Y, Sites JW (2005) Phylogeography and species limits in the Gymnodactylus darwinii complex (Gekkonidae, Squamata): genetic structure coincides with river systems in the Brazilian Atlantic Forest. Biological Journal of the Linnean Society, 85, 13-26.

Peres CA, Patton JL, da Silva MN (1996) Riverine barriers and gene flow in Amazonian saddleback tamarins. Folia Primatologica, 67, 113-124.

Posada D (1999) collapse (version 1.1). Department of Zoology, Brigham Young University, Salt Lake City, UT.

Posada D, Crandall KA (1998) Modeltest: testing the model of DNA substitution. Bioinformatics, 14, 817-818.

Posada D, Crandall KA (2001) Intraspecific gene genealogies: trees grafting into networks. Trends in Ecology E Evolution, 16, 37-45.

Rabemananjara F, Bora P, Cadle JE et al. (2005) New records, potential distribution and conservation of Mantella bernhardi, and endangered frog species from south-eastern Madagascar. Oryx, 39 (3), 335-338.

Raxworthy CJ, Nussbaum RA (2000) Extinction and extinction vulnerability of amphibians and reptiles in Madagascar. Amphibian and Reptile Conservation, 2, 15-23.

Ronquist F, Huelsenbeck JP (2003) Mrbayes3: Bayesian phylogenetic inference under mixed models. Bioinformatics, 19, 1572 1574

Rozas J, Sánchez-DeI, Barrio JC, Messeguer X, Rozas R (2003) DNASP, DNA polymorphism analyses by the coalescent and other methods. Bioinformatics, 19, 2496-2497.

Ryder OA (1986) Species conservation and systematics: the dilemma of subspecies. Trends in Ecology \& Evolution, 1, 9-10.

Steinfartz S, Veith M, Tautz D (2000) Mitochondrial sequence analysis of Salamandra taxa suggests old splits of major lineages and postglacial recolonizations of Central Europe from distinct source populations of Salamandra salamandra. Molecular Ecology, 9, 397-410.

Sterling E, Ramarason MG (1996) Rapid assessment of the primate 
fauna of the eastern slopes of the Réserve Naturelle Intégrale d'Andringitra, Madagascar. In: Floral and Faunal Inventory of the Eastern Slopes of the Réserve Naturelle Intégrale d'Andringitra, Madagascar: with Reference to Elevational Variation (ed. Goodman SM). Fieldiana Zoology, 85, 293-305.

Stuart SN, Chanson JS, Cox NA et al. (2004) Status and trends of amphibian declines and extinctions worldwide. Science, 306, $1783-1786$.

Swofford DL (2002) PAUP*. Phylogenetic analysis using parsimony ( ${ }^{*}$ and other methods). Version 4.0. Sinauer, Sunderland, Massachusetts.

Templeton AR, Sing CF (1993) A cladistic analysis of phenotypic associations with haplotypes inferred from restriction endonuclease mapping. IV. Nested analyses with cladogram uncertainty and recombination. Genetics, 134, 659-669.

Templeton AR, Crandall KA, Sing CF (1992) A cladistic analysis of phenotypic associations with haplotypes inferred from restriction endonuclease mapping and DNA sequence data. III. Cladogram estimation. Genetics, 132, 619-633.

US Fish and Wildlife Service and National Marine Fisheries Service (1996) Policy regarding the recognition of distinct vertebrate population segments under the Endangered Species Act. Federal Register, 61, 4721-4725.

Vallan D (2003) Consequences of rain forest fragmentation for herpetofauna: a case study from Ambohitantely. In: The Natural History of Madagascar (eds Goodman SM, Benstead JP), pp. 899 907. University of Chicago Press, Chicago and London.

Vences M, Glaw F, Böhme W (1999) A review of the genus Mantella (Anura, Ranidae, Mantellinae): taxonomy, distribution and conservation of Malagasy poison frogs. Alytes, 17 (1-2), 3-72.

Vences M, Vieites DR, Glaw F et al. (2003) Multiple overseas dispersal in amphibians. Proceedings of the Royal Society of London. Series B, Biological Sciences, 270, 2435-2442.

Vences M, Chiari Y, Raharivololoniaina L, Meyer A (2004) High mitochondrial diversity within and among populations of Malagasy poison frogs. Molecular Phylogenetics and Evolution, 30, 295-307.

Vences M, Thomas M, van der Meijden A, Chiari Y, Vieites DR
(2005) Comparative performance of the $16 \mathrm{~S}$ rRNA gene in DNA barcoding of amphibians. Frontiers in Zoology, 2, article 5.

Wake DB, Jockusch EL (2000) Detecting species borders using diverse data sets. In: The Biology of Plethodontid Salamanders (eds Bruce RC, Jaeger RG, Houck LD), pp. 95-119. Kluwer Academic/ Plenum Publishers, New York.

Wallace AR (1852) On the monkeys of the Amazon. Proceedings of the Zoological Society of London, 20, 107-110.

Wyner YM, Johnson SE, Stumpf RM, de Salle R (2002) Genetic assessment of a white-collared $\mathrm{x}$ red-fronted lemur hybrid zone at Andringitra, Madagascar. American Journal of Primatology, 67, 51-66.

David R. Vieites is a postdoctoral researcher at the University of California, Berkeley, with a special interest in phylogeographical patterns and conservation of amphibians and reptiles of Madagascar. This study is part of Ylenia Chiari's PhD research. Her research interests focus on the conservation genetics and phylogeography of endangered Malagasy herpetofauna. The research was carried out in the laboratory of Axel Meyer at the University of Konstanz, Germany. Miguel Vences, previously at the University of Amsterdam and currently professor for evolutionary biology at the Technical University of Braunschweig, is a specialist of the biogeography and evolution of the vertebrates of Madagascar, especially amphibians and reptiles, and his research interests currently focus on understanding the speciation mechanisms that generated Madagascar's extraordinary biodiversity. Franco Andreone is curator at the Natural History Museum in Turin, and is conducting conservation and taxonomic studies on the Malagasy herpetofauna, being currently chair of the Declining Amphibian Population Task Force (DAPTF/IUCN) for Madagascar. Falitiana Rabemananjara and Parfait Bora are carrying out their $\mathrm{PhD}$ and MSc theses, respectively, on the biology of Malagasy poison frogs at the Zoology Department of the University of Antananarivo. Sandra Nieto-Roman is a PhD student interested in biogeography and conservation of amphibians. 